\title{
New Media and the Work of Slovak Composer Tadeáš Salva
}

\author{
Michal Ščepán / michal.scepan@savba.sk
}

The Institute of Musicology, Slovak Academy of Sciences, Bratislava, SK

\begin{abstract}
Tadeáš Salva was one of the most interesting and prolific Slovak composer of the last century. His inventive approach in connection with audiovisual and electroacoustic media brought to Slovak music extremely original works, first of their kinds. The first composition which name is Radio oratorio was one of first Slovak electroacoustic composition. Another strictly vocal work is Slovak first Radio Oratorio Margita and Besná. Salva is also author of opera Weeping, specifically composed for radio broadcasting. The opera consists of only two voices - soprano and basso and its performance demands quadrophonic performance from one part voice increasing to twelve in culmination point. This contributions dealing with above-mentioned works, their genesis, analysis and the partial problematic of application of new media and the principle of total artwork in Tadeáš Salva's compositions.
\end{abstract}

\section{Keywords}

Avant-garde, New Media, Ballad, Radio oratorio, Television opera, Radio opera

This article is the result of the project implementation Topography of Music in Slovakia in the Course of Centuries (No. 2/0050/17) supported by Scientific Grant Agency of the Ministry of Education, Science, Research and Sport of the Slovak Republic and the Slovak Academy of Sciences, Bratislava, 2017-2020. 
Tadeáš Salva (22. 10. 1937-3. 1. 1995) is by Slovak musicology considered as one of the most inventive and original Slovak composers of the last century. According the Dictionary of Slovak composers Salva's originality and individuality is based on the synthesis of archaic models of Slovak folk music with compositional techniques of New music. The result is compositions containing modal melodies together with counterpoint relations, very often are polyrhythmic and polymetric parts in combinations with principles of Lutosławski limited aleatory technique. The whole Salva's composition poetics was formed under the influence of so called Polish school, but his compositional approach is highly individual. Essential epitome of Salva's work are emotional distress compositions titled ballad, characteristics by mentioned attributes. In the center of Salva's composition thinking standing a human voice, by his words the most perfect musical instrument. ${ }^{1}$

Thus, the most important factors are: Salva's study in Poland, Slovak folk music inspirations, composer's attitude to human voice which is based on the experience with previous two elements and of course his own invention.

During his life, Salva worked in two major mass media organizations. As the chief of Music redaction of Czechoslovak radio in Košice, and as the dramaturge at Music redaction of Czechoslovak television in Bratislava. In these profession, he very soon realized and was aware the opportunity of extension and streaming music not only to its listeners but also to wider group of people. And of course this music was not usual respectively not in intentions of socialistic realism, but it was a new type of music by other words it was avant-garde music. Following part of this contribution is focused on Salva's asset in the use of mass media in favor of avant-garde musical thinking on a several works.

One of the most significant activities of musical life in Slovakia was formation and establishment of experimental electroacoustic studio in Bratislava in the year 1965. This step of young Slovak composers and sound engineers was the main condition for genesis of whole Slovak autonomous electroacoustic compositions. ${ }^{2}$ Here in this place, in year 1967 Salva as employee of radio institution created his first electroacoustic composition named Rozhlasové oratórium (Radio Oratorio).

With composer's staying in Poland and whole change of musical paradigm in the second half of twenty century is connected so called genre innovation, typical for Salva's works. For example this composition is not classical oratorio. In this piece in duration circa 15 minutes absolutely missing epic side as well as colossal orchestra its festive liturgical character and intention for interpretation at large stage in concert halls. Instead of that this composition is montage and collage derived from sources connected with very strong elements of Slovak rural environment: authentic sound recordings of church's bells from village Podolínec, pipe organ passages composed by composer himself, reciter declaims lyrics from chosen Slovak folk ballads Medzi horami (Between mountains), Búvaj, búvaj synáček môj (Sleep, sleep my son) and Vydala mamka, vydala dcéru

1 GODÁROVÁ, Katarína. Salva, Tadeáš. [Article]. In JURÍK, Marián - ZAGAR, Peter (eds.). 100 slovenských skladatelov. Bratislava: Národné hudobné centrum, 1998, p. 238.

2 CHALUPKA, Lubomír. Slovenská hudobná avantgarda. Štýlotvorné formovanie skladatelskej generácie nastupujúcej v 60. rokoch 20. storočia. Bratislava: Katedra hudobnej vedy FiF UK, 2011, pp. 95-98. 
(Mother issued daughter). There is also a mixed choir singing words and sentences from these ballads or phrases without wider semantic meaning (fig. 1). What is important, in this composition aren't used electronically generated sounds. Electroacoustic devices were used only to make final shape of composition what has been achieved mainly by filters, change of sound spectrum, speed transformation, then changing rhythm, color and mixing of bells into multiple layers. The role of speaker was narrated by Slovak actor Viliam Záborský who alongside his actor and pedagogic activities spent many time on artistic language and its research. Mainly due on his participation on this project this composition had many performances. This work was one of first compositions created in experimental studio in Bratislava, and it is the first and also last composition labeled oratorio composed specially for radio broadcasting in new Slovak music.

Salva's second valuable work is first Slovak television opera which name is Margita a Besná (Margita and Besná). In contrast for example Czech Republic or other mostly Western European countries the tradition of television opera in Slovakia was unknown. During the sixties on the pages of only Slovak scholarly musical magazine named Slovenská hudba (Slovak Music) was published number of studies dealing with problematic of creating first Slovak opera of this type. ${ }^{3}$ When Salva moved from Košice radio station to Bratislava television studio, here he found between his colleagues new creative background which motivated him to create opera of new type which until this time was in Slovakia totally absented. During the year 1971 he composed first Slovak television opera. As the libretto Salva with cooperation with colleague Veronika Vrbková used well known Slovak ballad Margita and Besná by famous Slovak romantic poet Ján Botto.

On this composition are interesting several things:

This opera is composed only for vocal performance which consists of two solo voices - soprano and alto, then mixed choir with four voices of every section. There are completely missing orchestra and musical instruments. There is one character which is not singing and his role is only as an expression dancer. Length of the opera is very short only 24 minutes.

The main idea of the composer was filming the whole opera in the exteriors of Slovak country and then, performance of opera on stage is impossible. Impulses to choosing libretto and whole concept strictly vocal work taking place in nature go back to Salva's childhood.

Story about Margita and Besná has been known since the 19th century and besides Ján Botto was used by many other authors. But Salva this story primarily knew from talking his grandfather who for most of his life was a rafter. This profession was in composer's birth village Lúčky in region of Liptov located in northern Slovakia one of the main form of livelihood with long tradition. In the past there wasn't dangerous place on Slovak river Váh like two rocks Margita and Besná situated in narrow meander, where rafters often drowned after crash. It was a tax, some kind of revenge for two women and man who after tragic events trough the paranormal

3 HRČKOVÁ, Nad’a. Niekol'ko problémov televíznej opery. Slovenská hudba, 1960, vol. 4, no. 6, p. 276; HRČKOVÁ, Nad’a. Vzájomná podmienenost’ televíznej opery a spoločnosti. Slovenska hudba, 1961, vol. 5, no. 8, p. 311; HRČKOVÁ, Nad’a. Opera v televízii. In Slovenská hudba, 1965, vol. 9, no. 9, p. 412-414. 


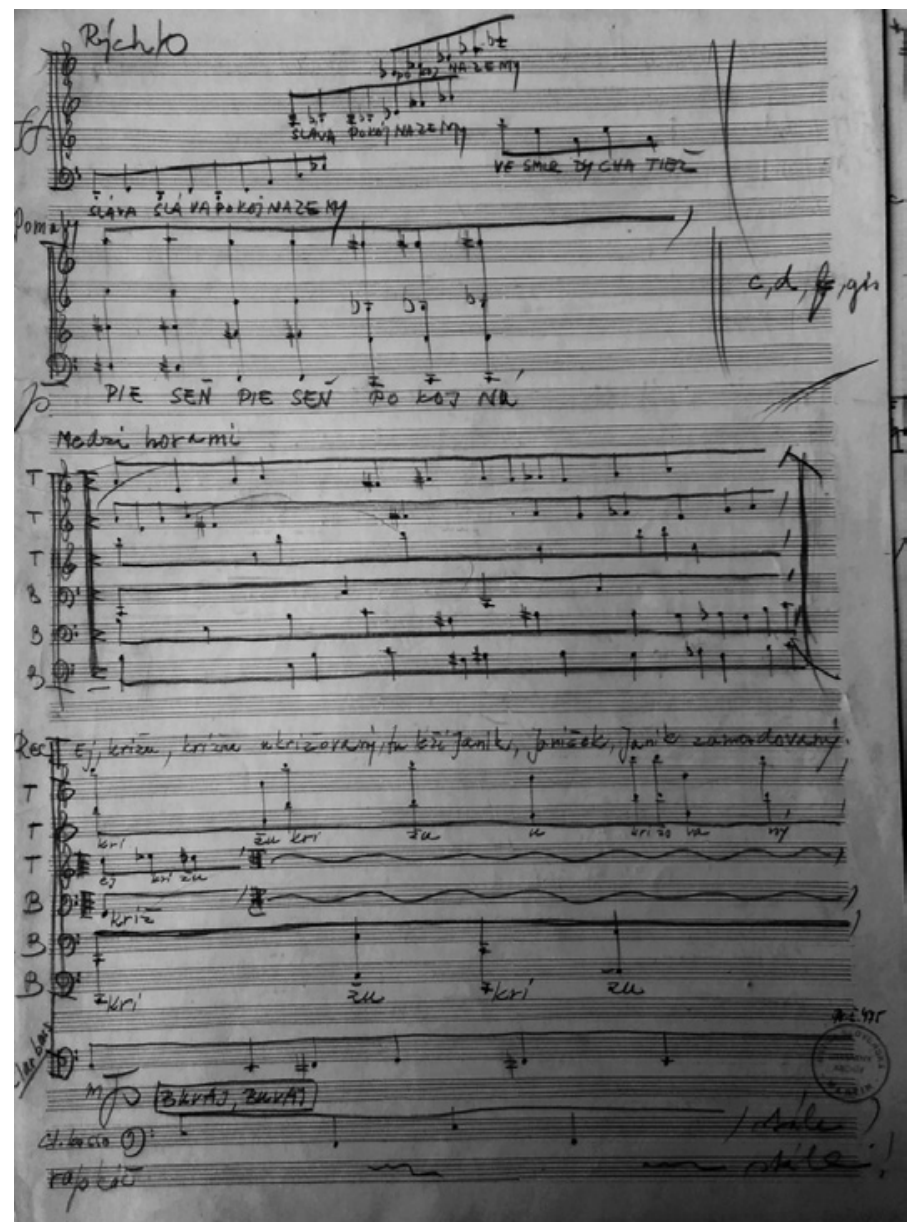

Fig. 1 Tadeáš Salva: Rozhlasové oratórium. Score, pp. 4.

forces were changed into a rocks with treacherous whirl between them. Among many rafting legends and songs this was the most known and is still alive until these days, although the rocks were detonated around the years 1937-1938. Therefore for this reasons Salva had decided as source of libretto chose ballad by Ján Botto. The original Botto ballad composer significantly changed and selected only main culmination points of this piece. Some parts of opera lyrics are absolutely new, for example the whole section of solo soprano is based on Salva's own text as well as on the other place lyrics sung by choir. In whole work is epic side in the background and more important is lyrical and dramatic elements.

The question why Salva didn't use any musical instrument has simple answer. If he want taking place of his opera in real nature the presence of musical instruments was unthinkable. Other aspect was also Salva's admiration of human voice and its use. In his 
birth village during his youth was strong tradition of so called meadow songs. ${ }^{4}$ Mountain environment around the village during singing made specific sound results which composer after getting strong impressions implanted into this work in forms of echo, parlando, rubato phrases, rhythmical thickening etc. ${ }^{5}$ The second aspect were works of composers represented by Polish composing school which Salva has opportunity to saw and listen at the festival Warsaw autumn during his study in Poland. Works as Witold Lutosławski's Three poems on Henry Micheaux, Krzystof Penderecki's Passion and Death of Our Lord Jesus Christ According to Saint Luke, or Henryk Górecki's Monologhi have brought completely new sonic and articulation options of vocal performance. So because of that all orchestra and instruments was in this opera substituted by mixed choir which has during the work also other functions. For example using the choir as declamation and commentator element was result of Salva admire and inspiration by old Greece antic drama. ${ }^{6}$ Salva because of that use in different musical situations various forms of text. When comprehensibility is necessary the words are continuously arranged in the context and on the other side, when is used as musical material there are occurring collocations and syllables coming from libretto as a result of manipulation ${ }^{7}$ or absolutely new mostly with asemantic meaning.

Choosing of balladic story has also its own explanation. As said on beginning of this contribution, during his life Salva composed circa 25 works named ballad for different occupation. The composer inclined to folk ballad and considered it as the most typical form for Slavic nations. In his study of this form he concluded that they are based on principle of two extremes for example like life and death, dark and light, day and night, sick and healthy etc. This dualistic contrast has according to him its reflection in all living in nature and because of that is ballad absolutely native form with long-term value. ${ }^{8}$ Salva in this opera which he considered as first work of balladic kind (although without word ballad in its name) applied these polarities in many various forms like homophony - polyphony, different musical material in superposition, two different characters good and bad in performance of two different voices and other possible contrasts.

Opera is divided into three parts: Prologue; main story line consisting of Aria of Margita, Aria of Besná with short connecting Recitative between them and final Epilogue.

Prologue is situated into open landscape with successive entry of each voice section parallel whit the main protagonist of the opera. Firstly Margita (soprano), then unknown young man as mute role, main antagonist Besná (alto) and choir characters - men with

4 URBANCOVÁ, Hana. Trávnice - lúčne piesne na Slovensku: Ku genéze, štruktúre a premenám piesñového žánru. Bratislava: AEPress, 2005.

5 ŠEBÍK, Ján. Ked’ umelec nie je doma prorokom - rozhovor s Tadeášom Salvom. Nedelná pravda, vol. 3 , no. 51, 23. 12. 1994, p. 7.

6 VAJDA, Igor. Slovenská opera. Bratislava: Opus, 1984, p. 178.

7 FECKER, Adolf. Sprache und Musik 2. Systematik der Vokalmusik. Hamburg: Verlag der Musikalienhandlung Karl Dieter Wagner, 1989, p. 244.

8 DÚBRAVSKÝ, Ján. Folklórne inšpirácie v tvorbe Tadeáša Salvu. In Osobnosti slovenskej hudobnej tvorby II. Zborník príspevkov z tretieho a štvrtého seminára Tadeáša Salvu. Zuzana Martináková - Egon Krák (eds). Banská Bystrica: Akadémia umení v Banskej Bystrici, 2006, p. 103. 


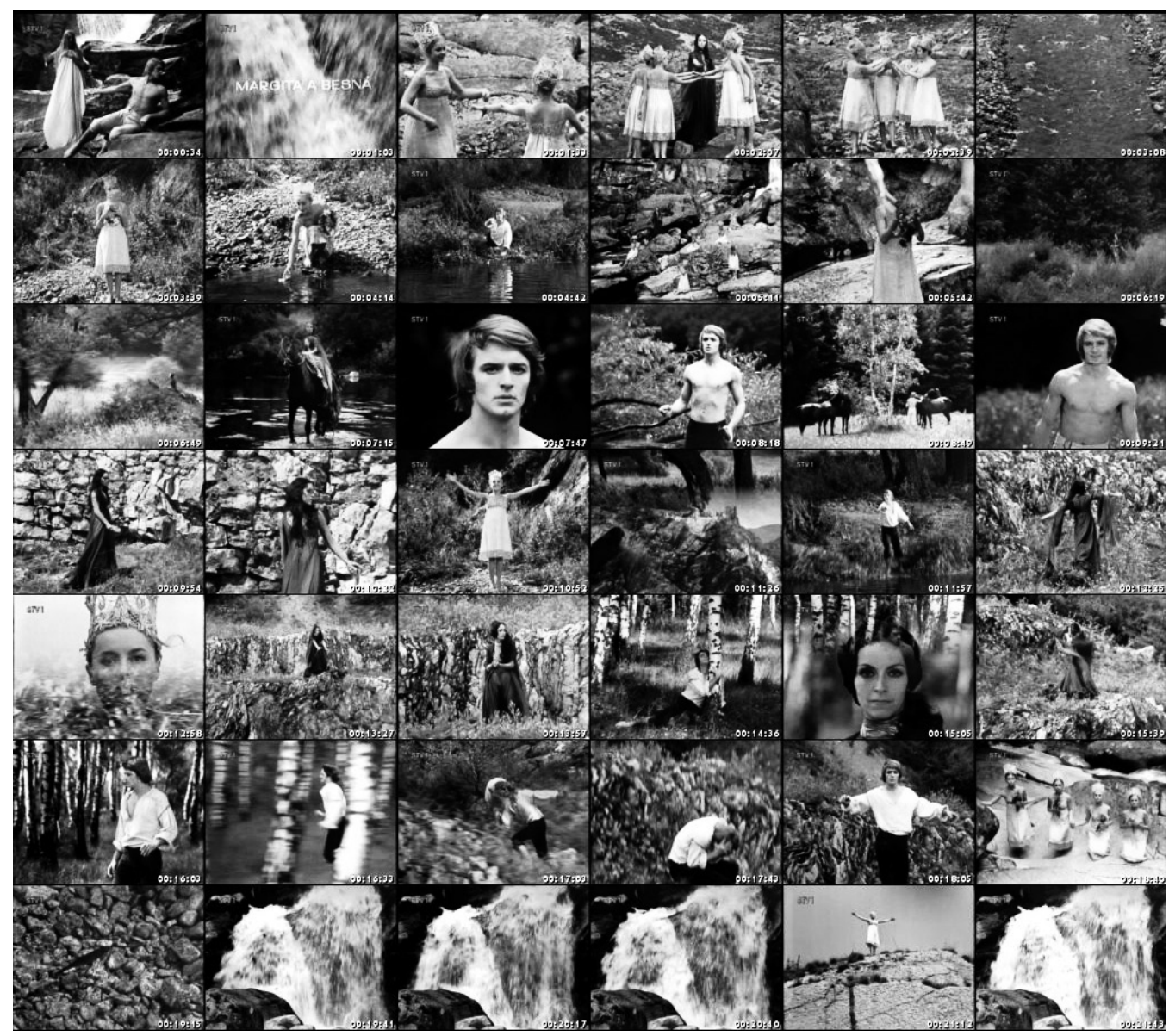

Fig. 2 Tadeáš Salva: Margita a Besná. Televízna opera, 1974, Thumbnail.

masks and young beautiful nymphs. In this part as well in whole opera the action is reduced only to pictures or hints of the story for example junction of the water springs are the symbol of connecting of two young people and beginning of love (fig. 2). The first Aria of Margita is only eleven words long with repetition some of them. Her innocent character of the singing fulfilled with pure love is in visual contrast - stepmother riding on the horse with seduction intensions on the young man. After short Recitative following Aria of Besná which is in comparison with the first Aria of Margita more complicated from the musical side and also brings within the plot the most relevant moments. In singing of Margita supported by mixed choir as reflection of her conscience in various forms of emotional affects is illustrated whole story progress in three separately blocks. From hate and cruelty to fear, solitude, shame, helplessness and hopelessness, when jealous old woman killed her young and beautiful stepdaughter and then she killed herself too. Young man also dies at the end of story in culmination point similar to the catastro- 


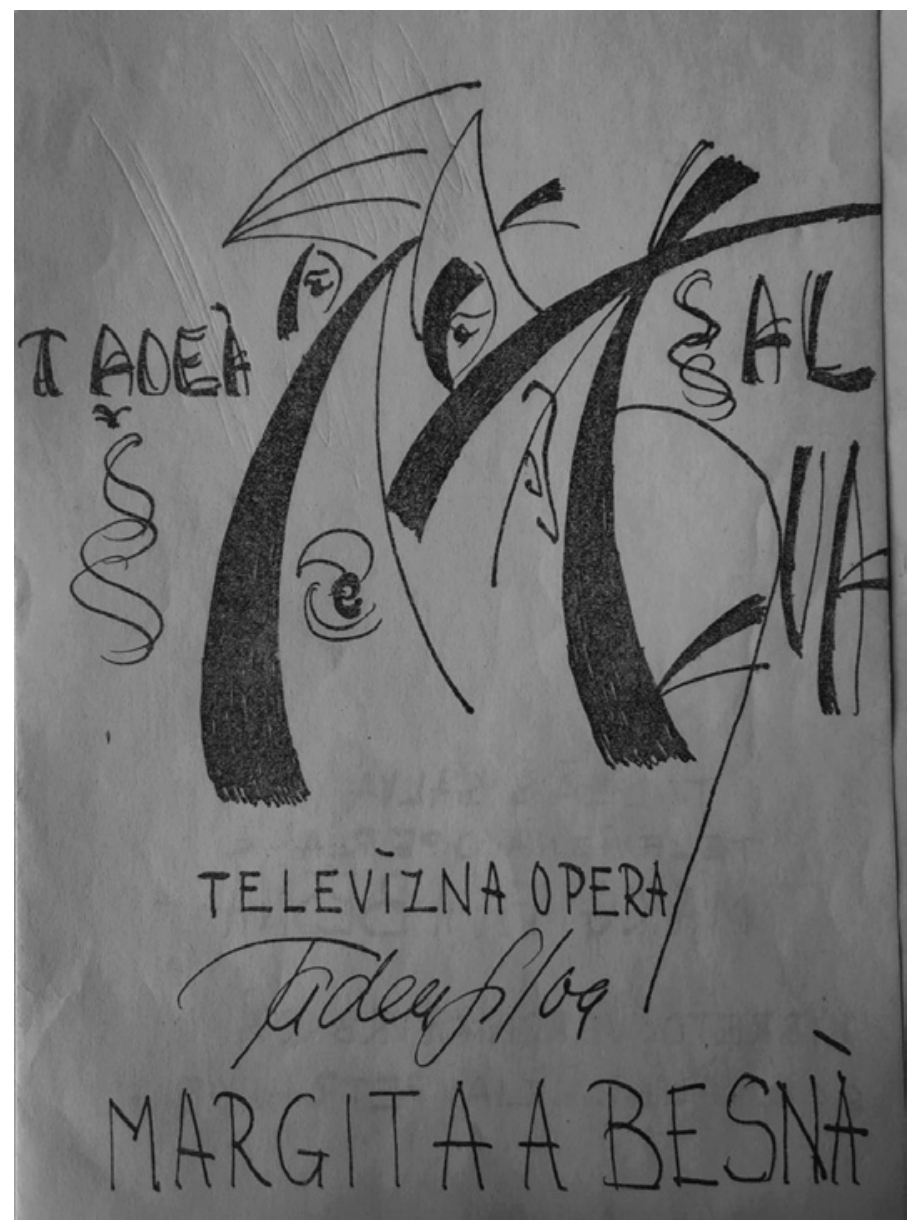

Fig. 3 Tadeáš Salva: Margita a Besná. Televízna opera, 1976, Drawing.

phe from antic tragedy. ${ }^{9}$ Final Epilogue brings the reminiscent pictures from beginning as the conclusion of permanent struggle of god and evil.

Salva beside his compositional activities was also the painter. If we speak about his compositional style, it can be easily compared with technique al fresco with rough contours where details are less important than the overall impression. What is interesting many of his musical works with these characteristics have their own pendant in his drawings and paintings. Among them are two with label Margita and Besná of which one of them with subtitle television opera (fig. 3). Furthermore, visual side of the opera's manuscript in case of leading voices, sound transparent optically reminds or corresponds with visual image of imagination of nature and the whole environment in which opera

9 LENGOVÁ, Jana. Princíp baladickosti v dielach Jána Levoslava Bellu a Tadeáša Salvu. Musicologia Slovaca. 2013, vol. 4 (30), no. 1, p. 74. 


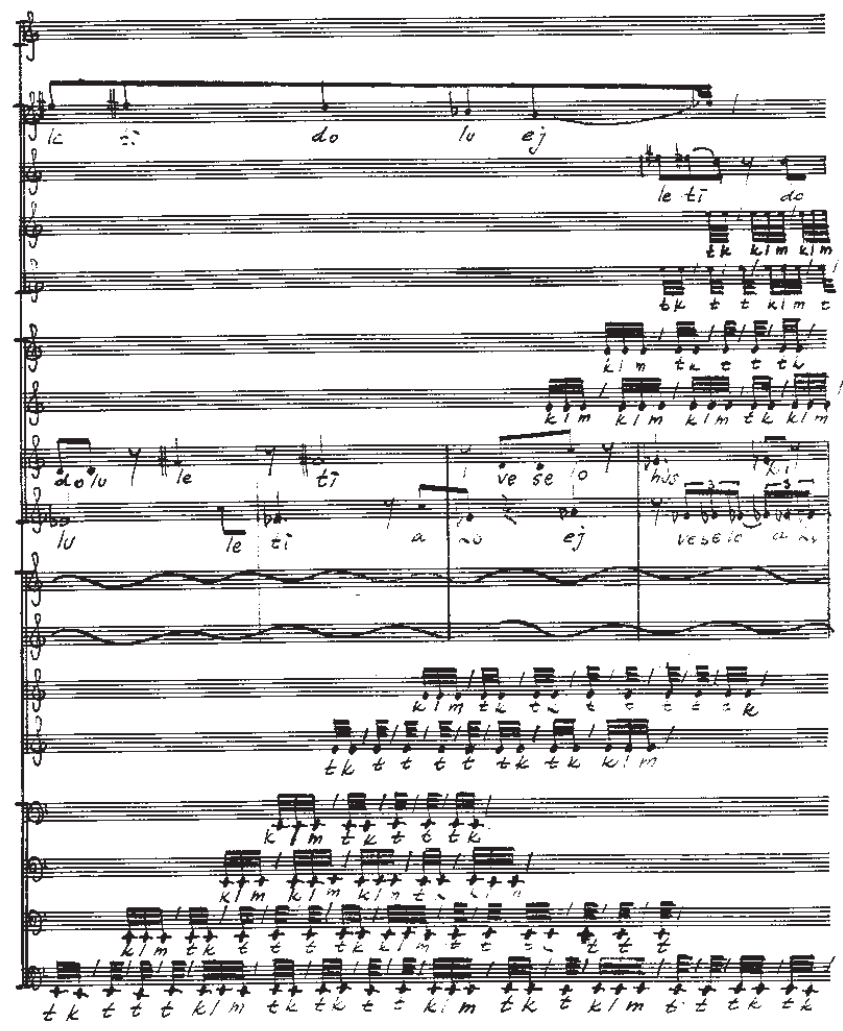

Fig. 4 Tadeáš Salva: Margita a Besná. Score, pp. 14.

occurring (fig. 4). This parallel musical facture and fine arts works points to the specific type of synesthesia. Salva in the footer of score noted his imaginations which are specific instructions for making whole movie (fig. 5). For the role of director of opera visual side was chosen Czech artist Petr Weigl. He more or less did not respect Salva's propositions and made whole movie after himself. More abstract Salva's concept he substituted under possibilities of the ongoing normalization with celebration of Slovak rich nature with hidden symbols of Christianity, old Slavonic and Antic. ${ }^{10}$ Musical interpretation of opera was performed by Slovakian Madrigalist ensemble with conductor Ladislav Holásek and soloist Magdaléna Hajóssyová and Ružena Ledecká in year 1972. Realization of visual side of opera was made in 1974. The main characters played by actors Magda Vášaryová, Dagmar Ledecká and Vlastimil Harapes.

The premiere took place at Christmas time on 16 December 1976 on the second channel of the Slovak television. The almost two-year delay was caused by the fact that work was still after its completion met with misunderstanding of several officials in television or Slo-

10 WEIGL, Peter. Príbehové obrázky a úryvok z televízneho scenára. Slovenská hudba, 1998, vol. 24, no. 4, p. 521. 


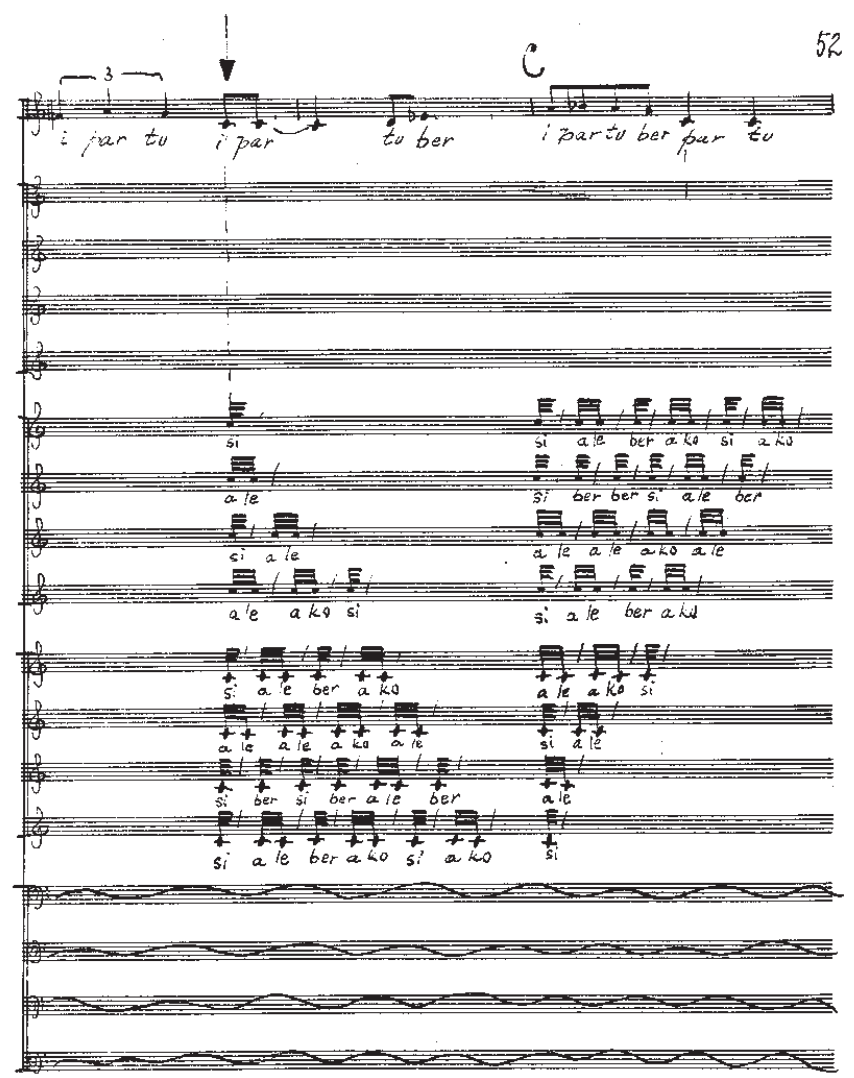

ZWENSUUSSA OBRAZ N+ VZDIALENEJSIEHO BEZZIACEHO MLADDENCA-

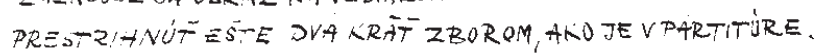

Fig. 5 Tadeáš Salva: Margita a Besná. Score, pp. 52.

vak composers union, with a recommendation for a complete redesign or shredding. With final premiere of the work paradoxically had helped poet and politician Vojtech Mihálik. Because of that foreword of this so called communist pope of poetry in Slovakia, explaining the principles of modern art in services of socialistic realism was broadcast before the premiere of the opera. It's interesting and also very curious that this preface was a part of every reprise even after year 1989 when communistic government in Czechoslovakia fallen down after events of The Velvet Revolution held on 17 November.

In spite of everything Tadeáš Salva created remarkable work dealing with permanent questions of usual life with connection with timeless ethical codex. According to its characteristics and synthesis auditive, visual, verbal, dancing and drawing it can be considered as total work of art. Salva's music together with usage of modern television technological resources make this work first of its kind which is today already a permanent part of not only Slovak music, but also represents an milestone in the modern Slovak cinematography. 

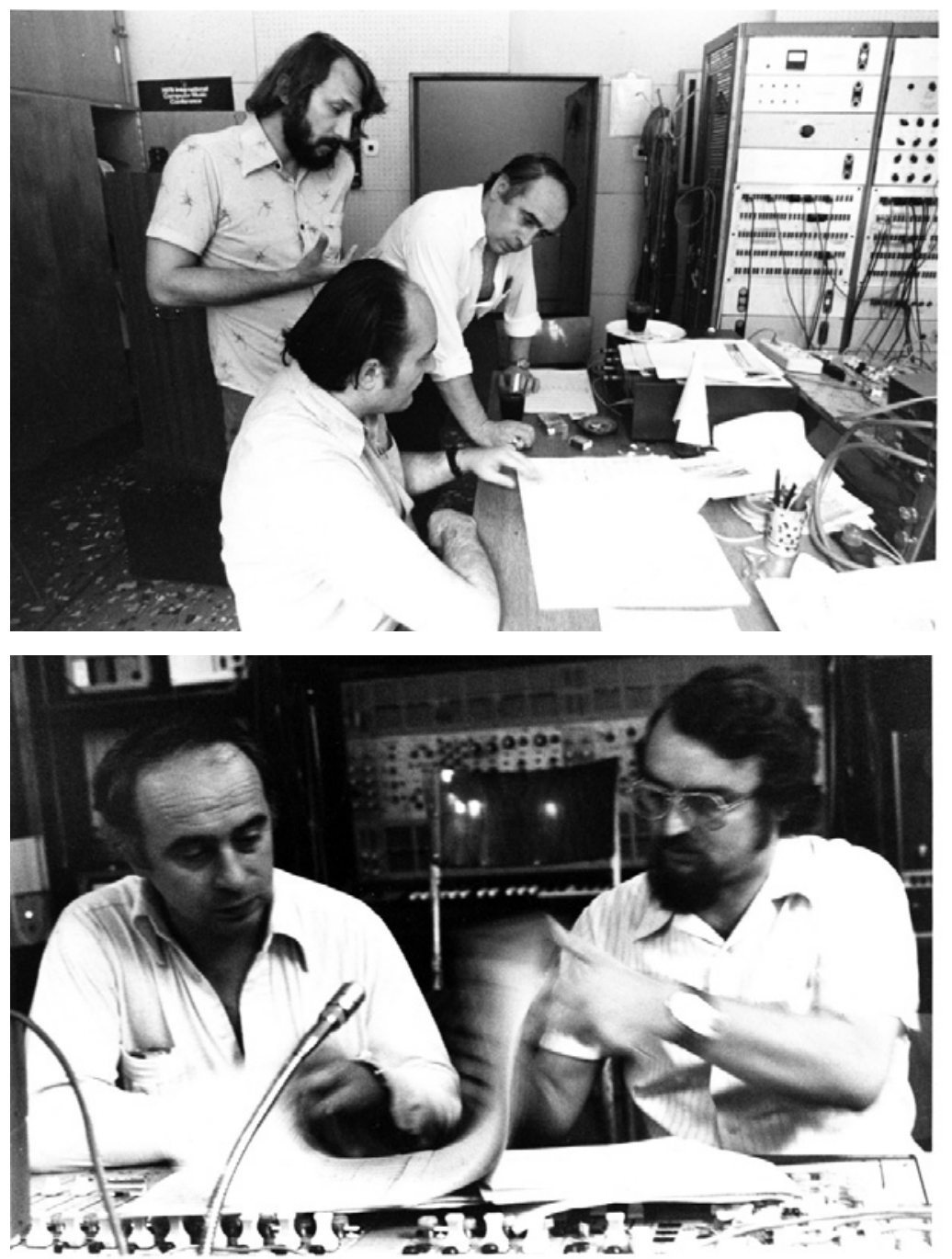

Fig. 6 Tadeáš Salva: Pictures from Electroacoustic studio in Bratislava during the realization of recording of quadrophonic opera Weeping, 1978.

Another Salva's composition has again its own primacy. Its name is Plač (Weeping) and its first Slovak quadrophonic radio opera. It was completed in year 1977 and realized two years after in experimental electroacoustic studio of Czechoslovak radio in Bratislava. As in the previous case, the instrumentation of opera consists of only vocal performers. The whole musical performance is sung only by two singers a man and a woman - bass and soprano whose voices arise by increasing from two to twelve. They have to express all dramatic tension: by color, dynamics and by the expression of the thinking and also substitute instrumental, choir and other soloist parts. At realization were used one eight 


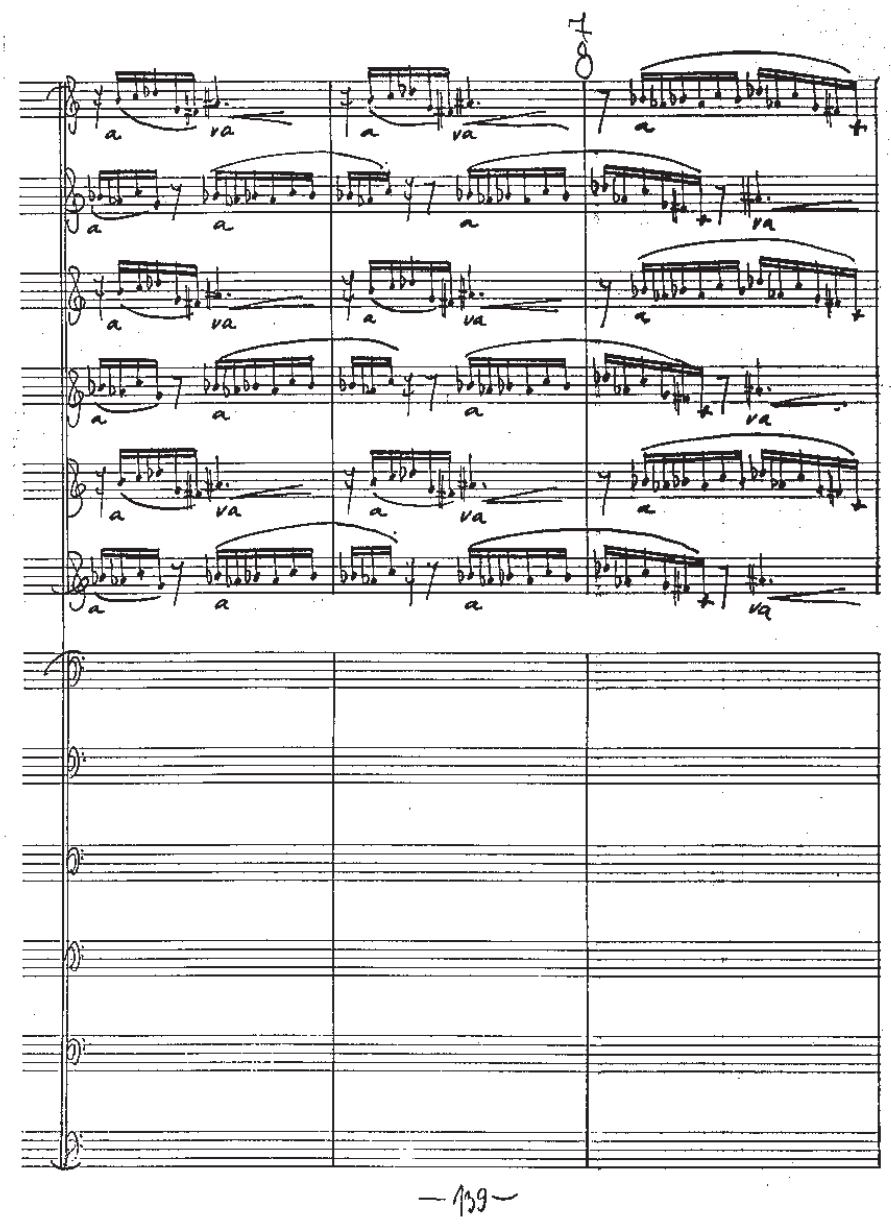

Fig. 7 Tadeáš Salva: Plač. Score, pp. 139.

tracks and one four track recorders on which was every voice recorded separately (fig. 6). By multiplayback technique were the voices mixed into final sound shape without use any electroacoustic sound except smooth synthetic reverb. After that, was all musical process divided into quadrophonic space according composer's sound imagination. The question why Salva demanded quadrophonic realization has its answer again in composer's childhood experience. Primarily, it weren't technical options of electroacoustic technology, but memories from his elementary school. According his words in his village school was teacher who before singing divided children into four corners of class. Then using for example canons and other voice alternations and so he achieved very interesting sound results which motivated children to singing even more and more. ${ }^{11}$

11 GLOCKOVÁ, Mária. Verný svojím tónom. Rozhovor s rodákom, hudobným skladatelom Tadeášom Salvom. Smer, vol. 1, no. 16, 19. 7. 1991, p. 4. 


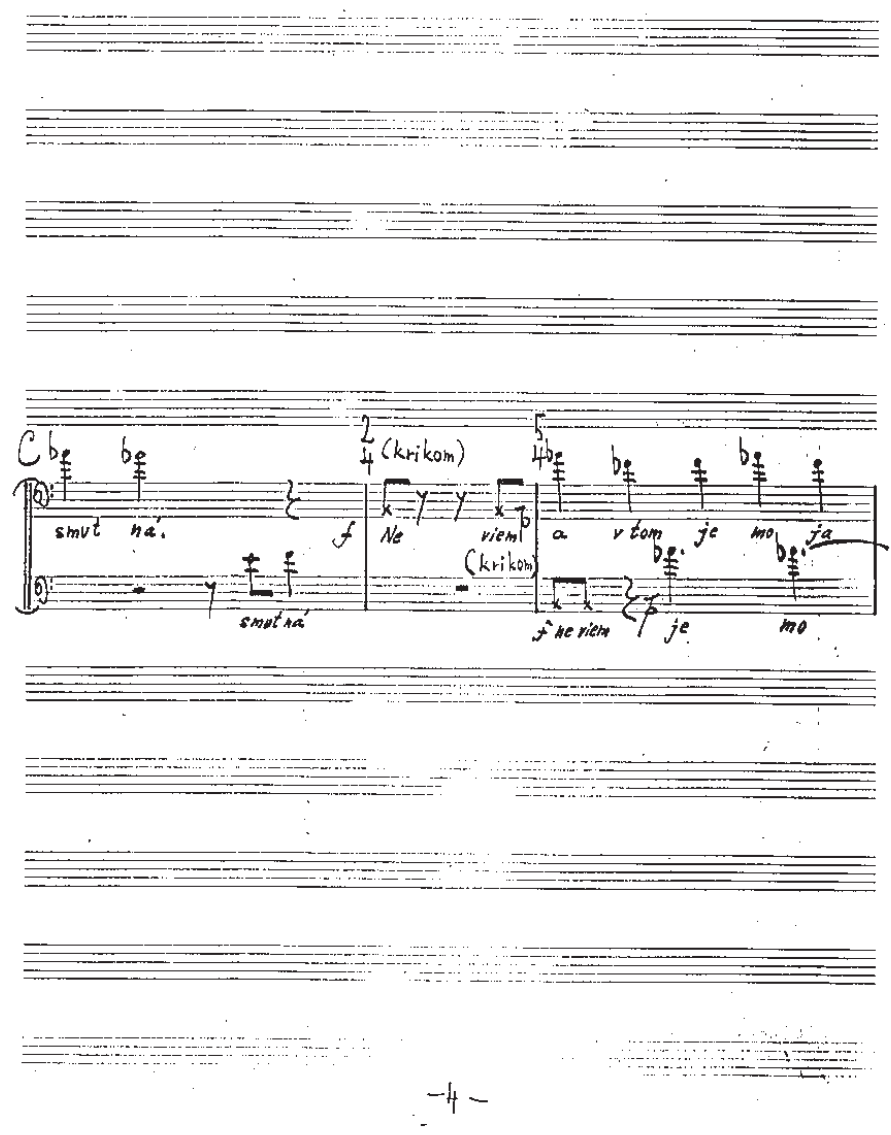

Fig. 8 Tadeáš Salva: Plač. Score, pp. 4.

In contrast to conventional radio works this opera has no story. Except epic side, is in this work also missing any dramatic conflict. They are both substituted by more philosophical intention. In weeping after all is concentrated many associative ideas and whole life experience, weeping can be not only reflection of saddens but also of joy and happiness. Weeping as type of lament has also very close to the ballad. In The Grove Dictionary of Music and Musicians within the definitions of ballad and lament is despite the fact that they are two different musical genres can be possible found also some complementary relations. Ballads in some cultures overlap with other genres which include lament, ${ }^{12}$ and on the other hand, lament as a kind of musical expression may be extended to ballads in

12 PORTER, James. Ballad. [Article]. In The New Grove Dictionary of Music and Musicians. Second Edition. Vol. 2. Stanley Sadie - John Tyrell (eds.). London: Macmillan Publishers, 2001, p. 545. 


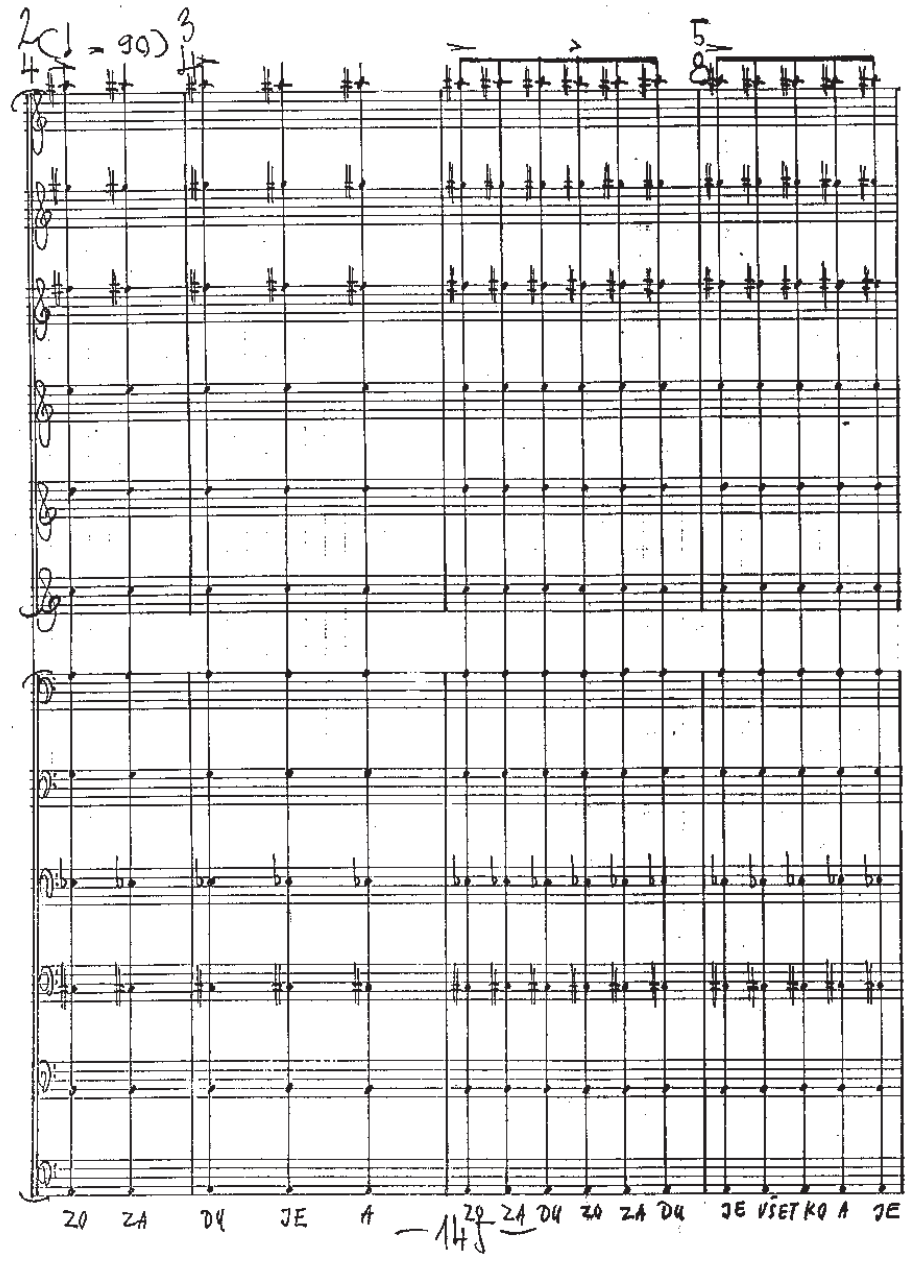

Fig. 9 Tadeáš Salva: Plač. Score, pp. 145.

through its two formal types: planctus - what is basically traditional weeping, and more structured form discourse as a type of more organized singing. ${ }^{13}$

For this specific intention Salva wrote his own libretto made up with montage of poems by five Slovak authors: Vladimir Mihálik, Fraňo Král', Vladimír Roy, Marcel Herz and Milan Rúfus. Whole opera is by usage of individual poems subdivided to 6 recitative parts with arioso refrain after every part. This refrain on the poem Death by Milan Rúfus is basically the textual leitmotiv every time on the same lyrics which created uniform atmosphere and whole idea of the work which length is approximately 27 minutes. Every

13 PORTER, James. Lament. [Article]. In The New Grove Dictionary of Music and Musicians. Second Edition. Vol. 14. Stanley Sadie - John Tyrell (eds.). London: Macmillan Publishers, 2001, p. 181.; LLOYD, Albert L.: Lament. [Article]. In The New Grove Dictionary of Music and Musicians. Vol. 10. Stanley Sadie - John Tyrell (eds.). London: Macmillan Publishers, 1980, p. 407. 


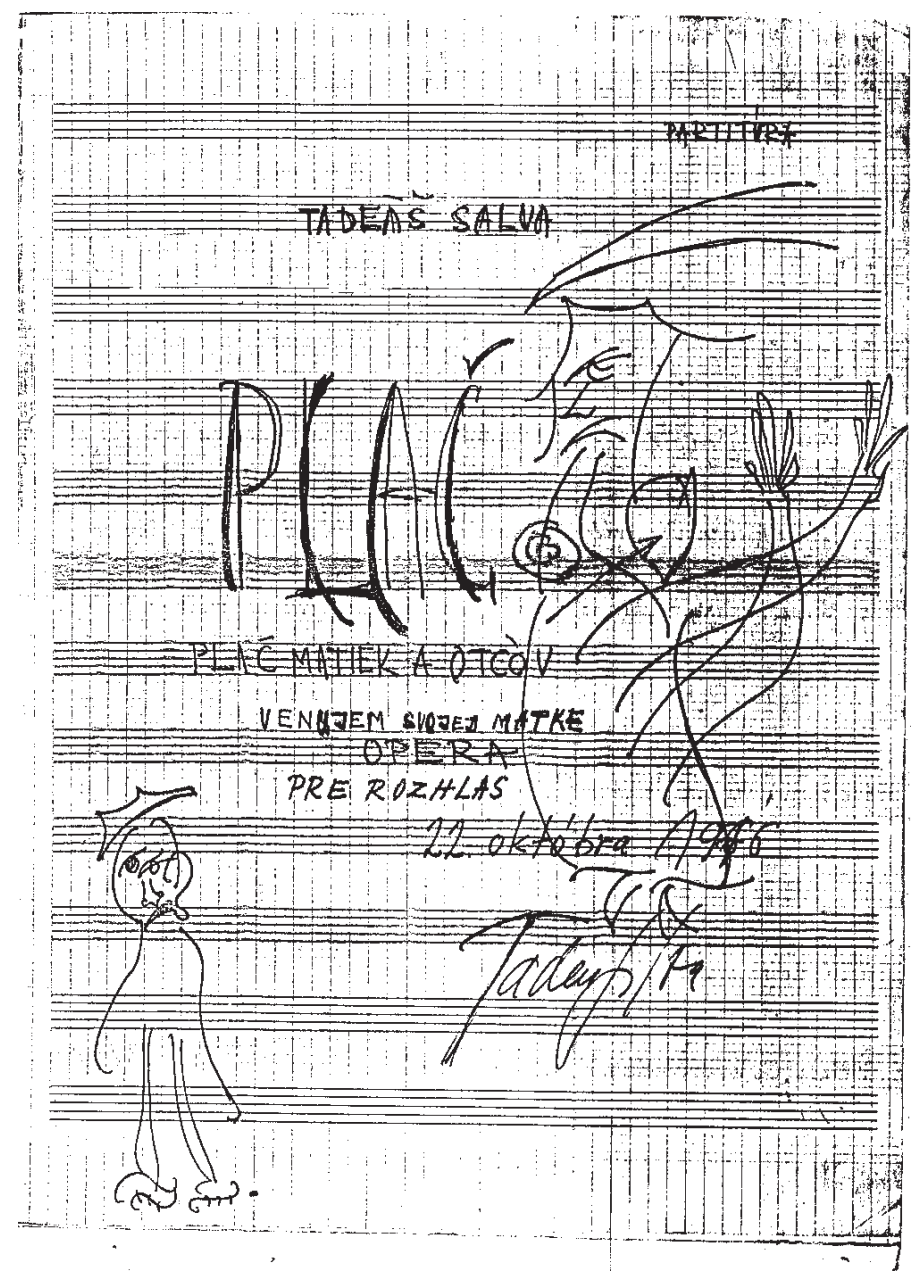

Fig. 10 Tadeáš Salva: Plač. Score, pp. 1.

part has its own character and containing different number of voices as well as the music of every refrain. Structure of the opera is following:

Opening recitative part of opera is two part voice dialogue of the man on the poem Allegro disordinato op. 21 by Vladimír Mihálik. After this, arioso of the man and the woman in the four part voices will sound. The second part is three part voice of the woman who in a declamatively melodious way performs the poem of Fraňo Král' - On the Day of All Souls. Incoming five part voice arioso consists of three voices sung by the woman and two by the man. Opera third part is based on the poem Rooks by Vladimir Roy with four voice part of the man with simultaneously sounding three part voice of the woman. Another arioso refrain subsequently creates intermezzo of whole opera and is based on six part voices melodic structure of the man and the woman. Part four is belonging to the man in four part voice, declaiming the poem Mosaic of Death by Marcel Herz. Eight 
part voice cantilena arioso brings the dialogue of the both performers. One part voice of woman brings in the fifth part lyrics Vladimír Mihálik's poem Allegro dissordinato op. 29. Melodic character of this voice is in contrast with the one part voice of the man which is whole time singing on single ostinato $g$-sharp note before eight part voice refrain. The shortest poem of the whole libretto is poem Boy by Milan Rúfus. This last part of the opera has nine part voice structure - five entrusted to the man and four to the woman. The last twelve part voice arioso refrain is reminiscence but also the climax of the musical process of the whole opera.

Even though at first sight, this composition is a purely experimental work it can be possible found here some hidden sings or traces typical for Slovak musical folklore. The composition as well as the opera Margita and Besná has its origin in period when for Salva's musical language was typical using these approaches. For example there is specific form of heterophony in polyphonic part (fig. 7), and then composer here used modality scales typical for the oldest Slovak folk songs, as well as often changing of meter. This last sing is result of perception of native, traditional singing. Salva after his experiences with meadow songs and other types of Slovak folk songs understands form of individual verses as the compact whole which cannot be framed into one regular bar. So, with the new phrase Salva also changes the metre - that means one phrase one meter, another new phrases another news meter which after all together creates one big uncorrupted polymetric blend (fig. 8, 9).

As in the previous case this work has also its visual art pendants - one right on the first page of opera score and second separate drawing (fig. 10). Opera had its own premiere on 12. January 1980 on radio station Devín. Quadrophonic realization was performed in the Moyzes Hall in Bratislava. All voices were performed by Elena Hanzelová, Sergej Kopčák under the conducting of Pavol Procházka. Final sound mixing and mastering of opera were made under supervision of sound engineers Peter Janík and Ján Backstuber. Until this day this work has any successor in this genre in Slovak music.

Specifics of new media works requires an interesting idea which realization lay on the precise length and form which demanding exact interpretation and its perfect formation. Tadeás Salva was in this field a pioneer, when on the broadcast strictly controlled by the communistic government enforced avant-garde motivated works whose quality may substantially affect the emotional aspects of audience in vivid experience while listening and watching them.

\section{Bibliography \\ Sources}

SALVA, Tadeáš. Oratórium. Autograph. SK-Msnk, sign. A LXII/1.

SALVA, Tadeáš. Margita a Besná. Pôvodná televizna opera na námet balady J. Bottu. Libreto napísala Veronika Vrbková. Autograph reproduction. Bratislava: Hudobný fond, 1972, 109 pp.

SALVA, Tadeáš. Margita a Besná. Televizna opera. Director Peter Weigl. Bratislava: Československá televízia, Hlavná redakcia hudobného vysielania, 1973-1974, 24 min. 
SALVA, Tadeáš. Margita a Besná. Separate drawing. SK-Msnk, sign. A CLXXXIV/1-706.

SALVA, Tadeáš. Plač. Plač matiek a otcov. Autograph reproduction. Bratislava: Hudobný fond, 1977, 155 pp.

\section{Literature}

DÚBRAVSKÝ, Ján. Folklórne inšpirácie v tvorbe Tadeáša Salvu. In Osobnosti slovenskej hudobnej tvorby II. Zbornik príspevkov z tretieho a šturtého seminára Tadeáša Salvu. Zuzana Martináková Egon Krák (eds). Banská Bystrica: Akadémia umení v Banskej Bystrici, 2006, pp. 103.

FECKER, Adolf. Sprache und Musik 2. Systematik der Vokalmusik. Hamburg: Verlag der Musikalienhandlung Karl Dieter Wagner, 1989.

GODÁROVÁ, Katarína. Salva, Tadeáš. [Article]. In JURÍK, Marián - ZAGAR, Peter (eds.). 100 slovenských skladatelov. Bratislava: Národné hudobné centrum, 1998, p. 238

GLOCKOVÁ, Mária. Verný svojím tónom. Rozhovor s rodákom, hudobným skladatelom Tadeášom Salvom. Smer, vol. 1, no. 16, 19. 7. 1991, p. 4.

HRČKOVÁ, Nad’a. Niekol'ko problémov televíznej opery. Slovenská hudba, 1960, vol. 4, no. 6, p. 276.

HRČKOVÁ, Nad’a. Vzájomná podmienenost̉ televíznej opery a spoločnosti. Slovenská hudba, 1961, vol. 5 , no. 8 , p. 311.

HRČKOVÁ, Nad’a. Opera v televízii. Slovenská hudba, 1965, vol. 9, no. 9, pp. 412-414.

CHALUPKA, Lubomír. Slovenská hudobná avantgarda. Štýlotvorné formovanie skladatelskej generácie nastupujúcej v 60. rokoch 20. storočia. Bratislava: Katedra hudobnej vedy FiF UK, 2011.

LENGOVÁ, Jana. Princíp baladickosti v dielach Jána Levoslava Bellu a Tadeáša Salvu. Musicologia Slovaca. 2013, vol. 4 (30), no. 1, p. 74.

LLOYD, Albert L.: Lament. [Article]. In The New Grove Dictionary of Music and Musicians. Vol. 10. Stanley Sadie - John Tyrell (eds.). London: Macmillan Publishers, 1980, p. 407.

PORTER, James. Ballad. [Article]. In The New Grove Dictionary of Music and Musicians. Second Edition. Vol. 2. Stanley Sadie - John Tyrell (eds.). London: Macmillan Publishers, 2001, p. 545.

PORTER, James. Lament. [Article]. In The New Grove Dictionary of Music and Musicians. Second Edition. Vol. 14. Stanley Sadie - John Tyrell (eds.). London: Macmillan Publishers, 2001, p. 181.

ŠEBÍK, Ján. Ked' umelec nie je doma prorokom - rozhovor s Tadeášom Salvom. Nedelná pravda, vol. 3, no. 51, 23. 12. 1994, p. 7.

URBANCOVÁ, Hana. Trávnice - lúčne piesne na Slovensku: Ku genéze, štruktúre a premenám piesňového žánru. Bratislava: AEPress, 2005.

VAJDA, Igor. Slovenská opera. Bratislava: Opus, 1984.

WEIGL, Peter. Príbehové obrázky a úryvok z televízneho scenára. Slovenská hudba, 1998, vol, 24, no. 4, p. 521. 